\title{
TRANSLATION OF IDIOMATIC EXPRESSION IN ROALD DAHL'S SHORT STORY "MAN FROM THE SOUTH" FROM ENGLISH INTO INDONESIAN
}

\author{
Lilis Susanti, Yuli Kuswardani \\ Department of English Teaching FPBS IKIP PGRI MADIUN \\ lilisshanty28@gmail.com,ikuswardaniae@gmail.com
}

\begin{abstract}
This research describes the translation strategy of idiomatic expression used by translator and the quality of translation of idiomatic expression in the short story by Roald Dahl entitled "Man from the South". This research uses descriptive qualitative method and uses content analysis as the data collection technique. To check the validity of this research, the researcher uses triangulation such as, data triangulation, investigator triangulation, theory triangulation, and methodological triangulation. The results of this research shows that several translation strategies are applied, which include idioms of similar meaning and form, translation by paraphrase, and translation by omission. In this research, paraphrase strategy is in the most applied strategy $87.88 \%$ of the data (58 idiomatic expressions) use translation by paraphrase. This research also shows that the quality of translation of idiomatic expression translation which consists of accuracy, naturalness, and clarity is categorized as good translation. It can be seen from the results that $75 \%$ of the data are accurate, $78,79 \%$ of the data are natural, and $78,79 \%$ of the data are clear.
\end{abstract}

Keyword: translation, idiomatic expression, translation strategy, quality of translation

\section{Introduction}

One of the ways that human do to make the communication through the written easily is by doing the translation. Based on Newmark (1981: 5), "translation is rendering the meaning of a text into another language in the way that the author intended the text."Short story is one of the text that translatedby the translator. However, there are some phrases or sentences that have different meaning with the meaning of constituents in short story. Moreover, Seidl and McMordie (1988: 13) say that idiom is group of words which have different meaning from the individual meaning of each word. It is also called as idiomatic expressionthat commonly use in almost languages in the world, because idiomatic expressions are used in a wide variety of contexts and situations. Idiomatic expressions should be translated well by the translator. It is important to be noticed, because it needs the technique and strategy to translate idiomatic expression. When the translator cannot translate the English idiom into Indonesian very well, it makes the meaning of the text will be different with the source language. The technique and 
strategy that the translator uses will influence the result of translation. A good translation can be seen by the quality of translation itself. When the quality of translation is good, it shows that the result of translation will be acceptable to reader in target language. The result of translation must be analyzed whether the result is kind of good translation or not. To produce a good translation, Larson (1988: 54) proposes three criteria to measure the quality of translation, such as accuracy, clearness, and naturalness. Therefore, the objectives of this research are to know the translation strategy and the quality of translation of idiomatic expression which measure with three scales there are accuracy, naturalness, and clarity in order to build good translation result.

\section{Method}

This research iss a descriptive qualitativeresearch because qualitative research approach focuses on the written form that uses multi method in analyzing the research. The researcher studies the phenomena by describing the data without manipulating the data. The researcher discovers the information from the data that will be analyzed.Data is divided into primary data and secondary data. The primary data in this research is taken from the "Man from the South" short story by Roald Dahl originally published in Collier's Magazine in 1948 (source language) and the translation of the short story into Indonesian (target language) on http://www.cerpenterjemahan.com/2014/07/man-from-south.html. The secondary data of this research is the result of the analysis of translation's quality from the investigator as the expert judgment of this research.

This research uses document or content analysis as the data collection technique. According to Ary et al., (2010: 29) content analysis focuses on analyzing and interpreting public records, textbooks, letters, films, tapes, diaries, themes, reports or other documents to learn about human behavior. Content analysis usually begins with a question that the researcher believes can best be answered by studying documents. Additionally, this research also uses questionnaire to collect the data. Based on Thomas (2003: 66) questionnaire is a printed set of questions that asked the participants to answer it. In questionnaire, the participant can answer by checking one choice from some possible answer or writing out the answer. This research asks the investigator as the participant and the expert judgment to give the score of the quality of translation by giving the checklist for each criteria of good translation. 
The researcher through the investigator will use the scale to measure the quality of translation in the short story. The scale that the investigator used to measure the quality of translation, such as accuracy, clarity, and naturalness are as follows:

Table 1 The scale of measuring translation accuracy

\begin{tabular}{|l|l|l|}
\hline \multicolumn{1}{|c|}{ Parameter Kualitatif } & Skor & $\begin{array}{l}\text { Kategori } \\
\text { Terjemahan }\end{array}$ \\
\hline $\begin{array}{l}\text { Makna kata, istilah teknis, frasa, klausa, kalimat atau teks } \\
\text { bahasa sumber dialihkan secara tidak akurat ke dalam bahasa } \\
\text { sasaran atau dihilangkan. }\end{array}$ & 1 & $\begin{array}{l}\text { Keakuratan } \\
\text { Rendah }\end{array}$ \\
\hline $\begin{array}{l}\text { Sebagian besar makna kata, istilah teknis, frasa, klausa, } \\
\text { kalimat atau teks bahasa sumber dialihkan secara akurat ke } \\
\text { dalam bahasa sasaran. Namun, masih terdapat distorsi makna } \\
\text { atau terjemahan makna ganda (taksa) atau ada makna yang } \\
\text { dihilangkan, yang mengganggu keutuhan pesan. }\end{array}$ & 2 & $\begin{array}{l}\text { Keakuratan } \\
\text { Sedang }\end{array}$ \\
\hline $\begin{array}{l}\text { Makna kata, istilah teknis, frasa, klausa, dan bahkan kalimat } \\
\text { bahasa sumber dialihkan secara akurat ke dalam bahasa } \\
\text { sasaran (bahasa Indonesia); sama sekali tidak terjadi distorsi } \\
\text { makna. }\end{array}$ & 3 & $\begin{array}{l}\text { Keakuratan } \\
\text { Tinggi }\end{array}$ \\
\hline
\end{tabular}

Source: Nababan, Nuraeni, and Sumardiono (2012: 50)

Table 2 The scale of measuring translation naturalness

\begin{tabular}{|c|c|c|}
\hline Parameter Kualitatif & Skor & $\begin{array}{c}\text { Kategori } \\
\text { Terjemahan }\end{array}$ \\
\hline $\begin{array}{l}\text { Terjemahan tidak alamiah atau terasa seperti karya } \\
\text { terjemahan; istilah teknis yang digunakan tidak lazim } \\
\text { digunakan dan tidak akrab bagi pembaca; frasa, klausa, dan } \\
\text { kalimat yang digunakan tidak sesuai dengan kaidah-kaidah } \\
\text { bahasa Indonesia }\end{array}$ & 1 & $\begin{array}{l}\text { Keberterimaan } \\
\text { Rendah } \\
\text { (Tidak } \\
\text { Berterima) }\end{array}$ \\
\hline $\begin{array}{l}\text { Pada umumnya terjemahan sudah terasa alamiah; namun ada } \\
\text { sedikit masalah pada penggunaan istilah teknis atau terjadi } \\
\text { sedikit kesalahan gramatikal dan kurang sesuai dengan } \\
\text { kaidah-kaidah bahasa Indonesia. }\end{array}$ & 2 & $\begin{array}{l}\text { Keberterimaan } \\
\text { Sedang } \\
\text { (Kurang } \\
\text { Berterima) } \\
\end{array}$ \\
\hline $\begin{array}{l}\text { Terjemahan terasa alamiah, istilah teknis yang digunakan } \\
\text { lazim digunakan dan akrab bagi pembaca; frasa, klausa, dan } \\
\text { bahkan kalimat yang digunakan sudah sesuai dengan kaidah- } \\
\text { kaidah bahasa Indonesia. }\end{array}$ & 3 & $\begin{array}{l}\text { Keberterimaan } \\
\text { Tinggi } \\
\text { (Berterima) }\end{array}$ \\
\hline
\end{tabular}

Source: Nababan et al., (2012: 51)

Table 3 The scale of measuring translation clarity/readability

\begin{tabular}{|l|l|l|}
\hline \multicolumn{1}{|c|}{ Parameter Kualitatif } & \multicolumn{1}{|c|}{ Skor } & \multicolumn{1}{|c|}{$\begin{array}{l}\text { Kategori } \\
\text { Terjemahan }\end{array}$} \\
\hline $\begin{array}{l}\text { Terjemahan sulit atau bahkan sangat sulit dipahami oleh } \\
\text { pembacanya. }\end{array}$ & 1 & $\begin{array}{l}\text { Keterbacaan } \\
\text { Rendah }\end{array}$ \\
\hline $\begin{array}{l}\text { Pada umumnya terjemahan dapat dipahami oleh pembacanya, } \\
\text { namun ada beberapa bagian yang harus dibaca lebih dari }\end{array}$ & 2 & $\begin{array}{l}\text { Keterbacaan } \\
\text { Sedang }\end{array}$ \\
\hline
\end{tabular}


satu kali untuk memahami terjemahan tersebut.

Kata, istilah teknis, frasa, klausa, dan bahkan kalimat dalam 3

terjemahan dapat dipahami dengan mudah oleh pembacanya.

Keterbacaan

Source: Nababan et al., (2012: 51)

The researcher uses triangulation as the technique of validating data. This research uses all types of triangulation. It uses data triangulation because this research uses some data such as the short story both in source language and target language, and the result of questionnaire. The investigator triangulation in this research is the use of two evaluators or investigators as the expert judgment. The investigator is someone who master in translation. Then, the researcher uses several theories about translation from some experts as the theory triangulation. The researcher also uses multiple methods such as document and questionnaire as the methodological triangulation. There are some activities that the researcher uses to analyze the data. According to Milles and Huberman (1994:10) data analysis technique are divided into three following activities:

a. Data Reduction

In this stage, the researcher finds the idiomatic expression in the source language and target language.

b. Data Display

The researcher organizes the list of idiomatic expression and then analyzes the translation strategy and the quality of translation in translating the short story.

c. Verification (Conclusion Drawing)

The researcher makes a conclusion based on the result of the research

\section{Results}

In the analysis of the data, the researcher describes the translation strategies use in translation of idiomatic expression into table below that consist of source language, target language, and translation strategy.

Table 4. Percentage of the translation strategies used in translation of idiomatic expression found in Roald Dahl's short story "Man from the South" which is translated into Indonesian.

\begin{tabular}{|c|l|c|c|}
\hline No. & Translation Strategy & Amount (idioms) & Percentage (\%) \\
\hline 1. & Translation by paraphrase & 58 & 87,88 \\
\hline 2. & Translation by omission & 6 & 0,09 \\
\hline 3. & $\begin{array}{l}\text { Using an idiom of similar meaning } \\
\text { and form }\end{array}$ & 2 & 0,03 \\
\hline
\end{tabular}




\begin{tabular}{|r|r|r|r|}
\hline 4. & $\begin{array}{l}\text { Using an idiom of similar meaning } \\
\text { but dissimilar form }\end{array}$ & - & - \\
\hline \multicolumn{2}{|r|}{ Total } & 66 & 100 \\
\hline
\end{tabular}

After collecting the data, the researcher finds that there are 66 idiomatic expressions found in Roald Dahl's short story entitled "Man from the South". There are three translation strategies that used in translation of idiomatic expression in Roald Dahl's short story "Man from the South" from English into Indonesian. The first and the most translation strategy that the translator uses is translation by paraphrase. It appears $58(87,88 \%)$, the second translation strategy is translation by omission that appears $6(0,09 \%)$ and the third is using an idiom of similar meaning and form that appears $2(0,03 \%)$.

\section{a. The Qualityof Translation}

In this research, the researcher describes the quality of translation that consists of accuracy, naturalness, and clarity into the table below. It consists of source language, target language, and the quality of translation.

Table 5. Accuracy of Translation of Idiomatic Expression in Roald Dahl's Short Story "Man from the South" from English into Indonesian.

\begin{tabular}{|c|l|c|c|c|c|c|}
\hline \multirow{2}{*}{ No. } & \multirow{2}{*}{$\begin{array}{c}\text { Quality of } \\
\text { Translation }\end{array}$} & $\begin{array}{c}\text { Amount } \\
\text { (idiom) }\end{array}$ & $\begin{array}{c}\text { Percentage } \\
(\mathbf{\%})\end{array}$ & $\begin{array}{c}\text { Amount } \\
\text { (idiom) }\end{array}$ & $\begin{array}{c}\text { Percentage } \\
(\mathbf{\%})\end{array}$ & $\begin{array}{c}\text { Percentage } \\
(\mathbf{\%})\end{array}$ \\
\hline 1. & Accurate & 45 & 68,18 & 54 & 81,82 & 75 \\
\hline 2. & Less accurate & 21 & 31,81 & 12 & 18,18 & 25 \\
\hline 3. & Inaccurate & - & - & - & - & - \\
\hline \multicolumn{2}{r|r}{ Total } & 66 & 100 & 66 & 100 & - \\
\hline
\end{tabular}

Based on table above, it shows that the accuracy of translation of idiomatic expression from the first expert are 45 idiomatic expressions $(68,18 \%)$ accurate, 21 idiomatic expressions $(31,81 \%)$ less accurate and there is no inaccurate idiomatic expressions. Whereas, the accuracy of translation of idiomatic expression from the second expert are 54 idiomatic expressions $(81,82 \%)$ accurate, 12 idiomatic expressions $(18,18 \%)$ less accurate, and there is no inaccurate idiomatic expression. It can be found that the accuracy of translation of idiomatic expression is $75 \%$ accurate and $25 \%$ less accurate.

Table 6. Naturalness of Translation of Idiomatic Expression in Roald Dahl's Short Story "Man from the South" from English into Indonesian 


\begin{tabular}{|c|c|c|c|c|c|c|}
\hline \multirow[b]{2}{*}{ No. } & \multirow{2}{*}{$\begin{array}{l}\text { Quality of } \\
\text { Translation }\end{array}$} & \multicolumn{2}{|c|}{ Expert 1} & \multicolumn{2}{|c|}{ Expert 2} & \multirow{2}{*}{$\begin{array}{c}\text { Average } \\
\text { Percentage } \\
(\%)\end{array}$} \\
\hline & & $\begin{array}{c}\text { Amount } \\
\text { (idiom) }\end{array}$ & $\begin{array}{c}\text { Percentage } \\
(\%)\end{array}$ & $\begin{array}{c}\text { Amount } \\
\text { (idiom) }\end{array}$ & $\begin{array}{c}\text { Percentage } \\
(\%)\end{array}$ & \\
\hline 1. & Natural & 44 & 66,67 & 60 & 90,90 & 78,79 \\
\hline 2. & Less natural & 16 & 24,24 & 6 & 9,09 & 16,67 \\
\hline 3. & Unnatural & 6 & 9,09 & - & - & 9,09 \\
\hline & Total & 66 & 100 & 66 & 100 & - \\
\hline
\end{tabular}

Based on table above, it shows that the naturalness of translation of idiomatic expression from the first expert are 44 idiomatic expressions $(66,67 \%)$ natural, 16 idiomatic expressions $(24,24 \%)$ less natural, and 6 idiomatic expressions $(9,09 \%)$ unnatural. Whereas, the naturalness of translation of idiomatic expression from the second expert are 60 idiomatic expressions $(90,90 \%)$ natural, 6 idiomatic expressions $(18,18 \%)$ less natural, and there is no unnatural idiomatic expressions. It can be found that the naturalness of translation of idiomatic expression is $78,79 \%$ natural, $16,67 \%$ less natural, and 9, 09\% unnatural.

Table 7. Clarity of Translation of Idiomatic Expression in Roald Dahl's Short Story "Man from the South" from English into Indonesian

\begin{tabular}{|c|l|c|c|c|c|c|}
\hline \multirow{2}{*}{ No. } & \multirow{2}{*}{$\begin{array}{c}\text { Quality of } \\
\text { Translation }\end{array}$} & $\begin{array}{c}\text { Amount } \\
\text { (idiom) }\end{array}$ & $\begin{array}{c}\text { Percentage } \\
(\mathbf{\%})\end{array}$ & $\begin{array}{c}\text { Amount } \\
\text { (idiom) }\end{array}$ & $\begin{array}{c}\text { Percentage } \\
(\mathbf{\%})\end{array}$ & $\begin{array}{c}\text { Percentage } \\
\mathbf{( \% )}\end{array}$ \\
\hline 1. & Clear & 53 & 80,30 & 51 & 77,27 & 78,79 \\
\hline 2. & Less Clear & 13 & 19,70 & 15 & 22,73 & 21,22 \\
\hline 3. & Unclear & - & - & - & - & - \\
\hline \multicolumn{2}{r}{ Total } & 66 & 100 & 66 & 100 & - \\
\hline
\end{tabular}

Based on table above, it shows that the clarity of translation of idiomatic expression from the first reader are 53 idiomatic expressions $(80,30 \%)$ clear, 13 idiomatic expressions $(19,70 \%)$ less natural, and there is no unclear idiomatic expressions. Whereas, the clarity of translation of idiomatic expression from the second reader are 51 idiomatic expressions (77, $27 \%$ ) clear, 15 idiomatic expressions $(22,73 \%)$ less clear, and there is no unclear idiomatic expressions. It can be found that the clarity of translation of idiomatic expression is $78,79 \%$ clear and 21 , and $22 \%$ less clear.

\section{Discussion}

The translation strategy of idiomatic expression can be categorized into four strategies. Baker (1992: 72) classifies four strategies in translation of idiomatic expressions, there are: (1) Using an idiom of similar meaning and form; (2) Using an idiom of similar meaning but 
dissimilar form; (3) Translation by paraphrase; and (4) Translation by omission. In the short story "Man from the South" by Roald Dahl which is translated into Indonesian, there are three translation strategies used such as using an idiom of similar meaning and form, translation by paraphrase; and translation by omission.

1. Translation by paraphrase

The most translation strategy used is translation by paraphrase that appears 58 times or $87,88 \%$. The examples of translation by paraphrase can be seen as follows:

SL: In the pool itself there were three or four girls and about a dozen boys, all splashing about

TL: Di kolam itu sendiri ada sekitar tiga atau empat wanita dan selusin lelaki, memercikkan air di sekitar mereka

From the first example above, the translator uses translation by paraphrase in translating the idiomatic expression 'all splashing about' into the word 'memercikkan air di sekitar mereka'. Although, the word 'all' means 'semua', 'splash' means 'memercikan air' and the word 'about' means 'disana-sini' the translator make it simple and clear when translate the phrase 'all splashing about' into the word 'memercikkan air di sekitar mereka'. It uses paraphrase because the translator cannot find the right equivalent or any idiom in the target language. Using this kind of strategy a translator transfers the meaning of an idiom using a single word or a group of words which roughly corresponds to the meaning of idiom but it is not an idiom itself.

The result of this research is similar to the previous research which is conducted by Eva Novianti (2012) in her research entitled "An Analysis of the Translation Strategies of Idiomatic Expressions in Lewis Carroll's Alice in Wonderland in its Translation by Khairi Rumantati". The other research that suitable with this result of the research is "Idioms and Strategies of Translation in Harry Potter and the Deathl yHallows" which is conducted by Rizky Febriawan Saputro (2012). The similarity is about the result of the research which shows that the most translation strategy used by translator is translation by paraphrase.

2. Translation by omission

The second strategy that used is translation by omission that appears 6 times or $0,09 \%$. The examples of translation by omission can be seen as follows:

SL: I could see the clusters of big brown nuts hanging down underneath the leaves

TL: Aku dapat melihat gugusan buahnya yang berwarna kecoklatan dibawah daundaunnya. 
From the first example above, it shows that the translator uses translation by omission in translating idiomatic expression 'hanging down underneath' into the word 'di bawah'. Translation by omission is used because the phrase 'hanging down' is omitted. The translator does not translate the phrase 'hanging down' in order to make it more stylistic. The translation should sound natural as well as the source language. Therefore, the translator uses translation by omission in translating idiomatic expression because of the stylistic reason (Baker, 1992: 77).

3. Using an idiom of similar meaning and form

The third strategy used is using an idiom of similar meaning and form that appears twice or $0,03 \%$. The examples of translation by using an idiom of similar meaning and form can be seen as follows:

SL: He was very brisk and very animated, like a person organizing games at a children's party

TL: Dia melakukannya dengan tangkas dan menggebu-gebu, seperti seseorang yang sedang menyusun permainan pada pesta anak-anak

From the first example above, it shows that the translator uses translation by using an idiom of similar meaning and form in translating idiomatic expression. It happens because it consists of roughly the same meaning and has equivalent of lexical items. An idiom should be similar not only in its form but also in meaning, because, sometimes, an idiom that is of the same form may convey totally different meaning. (Baker, 1992: 72)

4. The Quality of Translation

a. Accuracy

Accuracy is one of three criteria of translation's quality that should be completed in doing translation. The process of translating the source language text must find the equivalence on the target language text.

1). Accurate

Based on the data above, the researcher finds $75 \%$ idiomatic expressions are accurate. It shows that almost of the idiomatic expressions are accurately translated. The accurate translation consists of sentences that mentioned as below.

\begin{tabular}{|c|c|c|}
\hline No. & Source Language Text & Target Language Text \\
\hline 19. & "Hey, now. Wait a minute." & "Hey, tunggu sebentar." \\
\hline
\end{tabular}


From the data above, the translator translates the idiomatic expression wait a minute into the phrase tunggu sebentar. According to English-Indonesian Dictionary by John M. Echols and Hassan Shadily, the word wait has meaning tunggu and the phrase a minute has meaning satu menit. When the phrase wait a minute is translated into tunggu sebentar, it is accurately translated because the translator can find the closest meaning of wait a minute idiomatic expression. Based on Nababan's, Nuraeni's, and Sumardiono's (2012: 39-57) statement that, “makna kata, istilah teknis, frasa, klausa, dan bahkan kalimat sumber dialihkan secara akurat ke dalam bahasa sasaran (Bahasa Indonesia), sama sekali tidak terjadi distorsi makna”. So, the word the idiomatic expression wait a minutewhich is translated into the phrase tunggu sebentar is categorized as accurate because the meaning of the target language text is completed taken from source language text without distortion meaning.

2). Less Accurate

Based on the data above, the researcher finds $25 \%$ idiomatic expressions in this research is categorized as less accurate. The less accurate translation consists of sentences that mentioned as below.

\begin{tabular}{|c|l|l|}
\hline No. & \multicolumn{1}{|c|}{ Source Language Text } & \multicolumn{1}{c|}{ Target Language Text } \\
\hline 4. & $\begin{array}{l}\text { I could see the clusters of big } \\
\text { brown nuts hanging down } \\
\text { underneath the leaves }\end{array}$ & $\begin{array}{l}\text { Aku dapat melihat gugusan } \\
\text { buahnya yang berwarna } \\
\text { kecoklatan di bawah daun - } \\
\text { daunnya. }\end{array}$ \\
\hline
\end{tabular}

From the data above, the translator translates the idiomatic expression hanging down underneath into the phrase di bawah. According to English-Indonesian Dictionary by John M. Echols and Hassan Shadily, the word hanging has meaning menggantung, the word down has meaning turun, and the word underneath has meaning di bawah. When the phrase hanging down underneath is translated into di bawah, there are some words that do not translated. The translator omits some word in translating idiomatic expression. Based on Nababan et al., (2012: 39-57) state that,

Sebagian besar makna kata, istilah teknis, frasa, klausa, kalimat atau teks bahasa sumber dialihkan secara akurat ke dalam bahasa sasaran. Namun, masih terdapat distorsi makna atau terjemahan makna ganda (taksa) atau ada makna yang dihilangkan, yang mengganggu keutuhan pesan. 
So, the idiomatic expression hanging down underneath which is translated into the phrase di bawahis categorized as less accurate because there is the meaning that omitted and it is not suitable with the context, so it can influence the unity of message. It should be changed into menggantung dibawah in order to make the message become unity. It shows that there is a few differences of the meaning between the source language and target language. It causes the accuracy of translation is less accurate.

b. Naturalness

Being natural is the requirement that has an important role in a good translation. Translation result is called natural when it does not sound foreign. The translator has to make the translation result as natural as possible. The translation result is natural when it is not even a translation, but an original translation on the target language.

1).Natural

Based on the data above, the researcher finds 78, 79\% idiomatic expressions are natural. It shows that almost of the idiomatic expressions are naturally translated. The natural translation consists of sentences that mentioned as below.

\begin{tabular}{|c|l|l|}
\hline No. & \multicolumn{1}{|c|}{ Source Language Text } & \multicolumn{1}{c|}{ Target Language Text } \\
\hline 15. & $\begin{array}{l}\text { The American boy held up } \\
\text { his lighter }\end{array}$ & $\begin{array}{l}\text { Pemuda Amerika tersebut } \\
\text { menawarkan pemantiknya }\end{array}$ \\
\hline
\end{tabular}

From the data above, the phrase held up has translated to menawarkan. According to English-Indonesian Dictionary by John M. Echols and Hassan Shadily, the word held has meaning memegang and the word up has meaning naik. Based on Nababan et al., (2012: 39-57) state that, “terjemahan terasa alamiah, istilah teknis yang digunakan lazim digunakan dan akrab bagi pembaca; frasa, klausa, dan bahkan kalimat yang digunakan sudah sesuai dengan kaidah-kaidah Bahasa Indonesia”. So, the phrase held upwhich is translated into memegang is categorized as natural because the sentence that translated from source language to target language is suitable with target language because it can make the reader in target language can understand the message easily.

\section{2).Less Natural}

In this research finds $16,67 \%$ idiomatic expressions are categorized as less natural translation. The less natural translation is mentioned as below.

\begin{tabular}{|l|l|l|}
\hline No. & Source Language Text & Target Language Text \\
\hline
\end{tabular}




\begin{tabular}{|c|l|l|}
\hline 5. & $\begin{array}{l}\text { In the pool itself there were } \\
\text { three or four girls and about a } \\
\text { dozen boys, all splashing } \\
\text { about }\end{array}$ & $\begin{array}{l}\text { Di kolam itu sendiri ada sekitar } \\
\text { tiga atau empat wanita dan selusin } \\
\text { lelaki, memercikkan air di } \\
\text { sekitar mereka }\end{array}$ \\
\hline
\end{tabular}

From the data above, the phrase splashing about has translated to memercikkan air di sekitar mereka. According to English-Indonesian Dictionary by John M. Echols and Hassan Shadily, the word splashing has meaning deburan and the word about has meaning disana-sini. Based on Nababan et al., (2012: 39-57) state that, "pada umumnya terjemahan sudah terasa alamiah; namun ada sedikit masalah pada penggunaan istilah teknis atau terjadi sedikit kesalahan gramatikal dan kurang sesuai dengan kaidah kaidah bahasa Indonesia”. So, the phrase splashing about which is translated into memercikkan air di sekitar mereka is categorized as less natural because there are some mistakes on using technical term or happened some mistake on grammatical and it is not suitable with rules of Indonesian. It causes the message from the source language has a difference and does not equivalent with the target language.

3).Unnatural

This research finds $9,09 \%$ idiomatic expressions which is categorized as not natural translation.

\begin{tabular}{|c|l|c|}
\hline No. & \multicolumn{1}{|c|}{ Source Language Text } & \multicolumn{1}{c|}{ Target Language Text } \\
\hline 11. & $\begin{array}{l}\text { he came bouncing along the } \\
\text { side of the pool, looking at the } \\
\text { people and the chairs }\end{array}$ & $\begin{array}{l}\text { Dia berjalan melewati sisi kolam } \\
\text { sambil memandangi orang - orang } \\
\text { dan kursi di sekitar sana }\end{array}$ \\
\hline
\end{tabular}

From the data above, the translator translates the idiomatic expression came bouncing along into the phrase berjalan melewati. According to English-Indonesian Dictionary by John M. Echols and Hassan Shadily, the word came has meaning datang, the word bouncing has meaning kuat, and the word along has meaning jalan terus. When the phrase came bouncing along is translated into berjalan melewati, there are some words that do not translated. Based on Nababan et al., (2012: 39-57) state that, "terjemahan terasa tidak alami atau terasa seperti karya terjemahan dan istilah tidak lazim digunakan dalam penerjemahan". There is deletion and the wrong of choosing the technical term of translation between source language and target language. So, the idiomatic expression came bouncing alongwhich is translated into the phrase berjalan melewati is categorized as not natural. The translation should be changed into sedang 
berjalan melewati, because it can make the message delivered well. It shows that there are a few differences of the meaning between the source language and target language.

\section{Clarity}

Clear is one of three criteria that have to use to measure the quality of translation. It is important to keep the meaning or the message constant from the source language to the target language but not make the readers confuse with the content when they are reading it.

1). Clear

This research finds $78,79 \%$ idiomatic expression which is categorized as clear translation. The clear translation is mentioned as below.

\begin{tabular}{|c|l|l|}
\hline No. & \multicolumn{1}{|c|}{ Source Language Text } & \multicolumn{1}{c|}{ Target Language Text } \\
\hline 34. & $\begin{array}{l}\text { You say we go up to your } \\
\text { room }\end{array}$ & $\begin{array}{l}\text { Katamu tadi, kita akan naik ke } \\
\text { kamarmu }\end{array}$ \\
\hline
\end{tabular}

From the data above, the phrase go up has translated to naik. According to English-Indonesian Dictionary by John M. Echols and Hassan Shadily, the word go has meaning pergi and the word up has meaning naik. Although the translator omits the word go in doing translation the idiomatic expression, the message and the meaning of source language does not change and the reader can understand easily. According to Nababan et al., (2012: 39-57) state that, "kata, istilah teknis, frasa, klausa, danbahkankalimatdalamterjemahandapatdipahamidenganmudaholehpembacanya". So, the phrase go upwhich is translated into naik is categorized as clear because the phrase in the source language text well translated on the target language. The result of translation is easy understood by the reader.

2). Less Clear

This research finds $21,22 \%$ idiomatic expression which is categorized as less clear translation. There are some of less clear translation is presented as below.

\begin{tabular}{|c|l|l|}
\hline No. & \multicolumn{1}{|c|}{ Source Language Text } & \multicolumn{1}{c|}{ Target Language Text } \\
\hline 9. & $\begin{array}{l}\text { They'd reached the stage } \\
\text { where they were diving under } \\
\text { the water and tipping them } \\
\text { up by their legs }\end{array}$ & $\begin{array}{l}\text { Mereka sudah sampai tahap di } \\
\text { mana mereka menyelam ke } \\
\text { dalam air dan menjungkitkan } \\
\text { kaki mereka }\end{array}$ \\
\hline
\end{tabular}


From the data above, the clause tipping them up by their legs has translated to menjungkitkan kaki mereka. According to English-Indonesian Dictionary by John M. Echols and Hassan Shadily, the word tipping has meaning menaikkan, the word up has meaning naik and the phrase by their legs has meaning dengan kaki mereka. The translator translates the phrase tipping them up into menjungkitkan. Based on Nababan et al., (2012: 39-57) state that, "pada umumnya terjemahan dapat dipahami oleh pembacanya, namun ada beberapa bagian yang harus dibaca lebih dari satu kali untuk memahami terjemahan tersebut". So, the word tipping them up by their legs which is translated into menjungkitkan kaki mereka is categorized as less clear because in general translation can be understood by the reader easily but there are some parts that should be read more than once to understand the translation itself.

\section{Conclusion}

This research has analyzed the translation strategy used in translation of idiomatic expression in short story entitled "Man from the south" into Indonesian. The researcher finds 66 idiomatic expressions in the short story. There are three translation strategies that used in translation of idiomatic expression in Roald Dahl's short story "Man from the South" into Indonesian. The most translation strategy uses is translation by paraphrase that appears 58 $(87,88 \%)$. This research also shows that the quality of translation of idiomatic expression translation which consists of accuracy, naturalness, and clarity is categorized as good translation. It can be seen from the results that $75 \%$ of the data are accurate, $78,79 \%$ of the data are natural, and78, 79\% of the data are clear.

\section{References}

Ade, Olaofe Isaac and Okunoye, Oyeniyi. (2008). An Introduction to Literature and Literary Criticism. Lagos: National Open University of Nigeria.

Ary, Donald et.al .(2010).Introduction to Research in Education ( $8^{\text {th }}$ Edition). Wadsworth: Cengage Learning.

Baker, M. (1992). In Other Words: A Course book on Translation. London: Routledge.

Basnet, Susan. (2002). Translation Studies ( $3^{\text {rd }}$ edition). London: Routledge.

Bell, T. Rogers. (1991). Translation and Translating. London: Oxford University.

Bogdan, Robert C. and Biklen, Sari Knopp. (2007). Qualitative Research for Education: An Introduction to Theories and Methods (5 $5^{\text {th }}$ edition). Boston: Pearson Education. Inc. 
Catford, J.C. (1965). A Linguistic Theory of Translation. London: OxfordUniversity Press.

Larson, Mildred L. (1998). Meaning Based Translation. New York: University Press of Amerika.

McCarthy, M. and O'dell, F. (2010). English Idioms in Use. Cambridge: CUP.

Mcculloch, Gary. (2004). Documentary Research in Education, History and the Social Sciences. London: Routledge Falmer.

Milles, Matthew B. and Huberman, A. Michael. (1994). Qualitative Data Analysis: An expanded sourcebook ( $2^{\text {nd }}$ edition). London: SAGE Publications.

Munday, Jeremy. (2008). Introducing Translation Studies: Theories and Applications (2 ${ }^{\text {nd }}$ edition). London: Routledge.

Nababan, M.R, Ardiana N dan Sumardiono. 2012. "Pengembangan Model Penilaian Kualitas Terjemahan." Kajian Linguistik dan Sastra. vol. 24. no: 1, hal 39 - 57.

Newmark, Peter. (1981). A Textbook of Translation. New York: Prentice Hall.

Nida, Eugene A. and Taber, Charles R. (1982). The Theory and Practice of Translation. Leiden: E.]. Brill.

Novianti, E. (2012). An Analysis of the Translation Strategies of Idiomatic Expressions in Lewis Carroll's Alice In Wonderland in its Translation by Khairi Rumantati. Unpublished. Yogyakarta: English Language and Literature Study ProgramYogyakarta State University.

Patton, Michael Quinn. (2002). Qualitative Research \& Evaluation Method (3 ${ }^{\text {rd }}$ edition). London: SAGE Publications.

Rodrigues, Raymond J. \& Badaczewski, Dennis. (1978). A Guidebook for Teaching Literature. Boston: Allyn and Bacon, Inc.

Rodriguez, J. K and Winnberg H. (2013). Teaching Idiomatic Expressions in Language Classrooms - Like the Icing on the Cake. Malmö högskola.

Saputro, R. F. (2012). "Idioms and Strategies of Translation in Harry Potter and the Deathly Hallows. ”Anglicist Vol. 01. No: 02, page: 23-28.

Seidl, J. and Mc Mordie, W. (1988). English Idioms and How to Use Them (5 $5^{\text {th }}$ edition). Jakarta: PT Intermasa.

Thomas, R. Murray. (2003). Blending Qualitative and Quantitative Research Methods in Theses and Dissertations. California: Corwin Press. Inc.

Yin, Robert K. (2011). Qualitative Research from Start to Finish. New York: The Guliford Press.

http://www.cerpenterjemahan.com/2014/07/man-from-south.html 
